\title{
Systems analysis of municipal solid waste management and recycling system in east Africa: benchmarking performance in Kigali city, Rwanda
}

\author{
Telesphore Kabera ${ }^{1}$, and Honorine Nishimwe ${ }^{2}$ \\ ${ }^{1}$ College of Science and Technology, University of Rwanda, P.O. Box 3900, Kigali, Rwanda \\ ${ }^{2}$ Development Bank of Rwanda, P.O. Box 1341, Kigali, Rwanda
}

\begin{abstract}
This study assessed the current status of solid waste management (SWM) in the City of Kigali (CoK), the capital city of Rwanda. This assessment was done using systems analysis methodology of "wasteaware" benchmark indicators for integrated sustainable waste management in cities. This method of assessing helps to assess the Municipal Solid Waste Management (MSWM) in a city according to its physical components and governance features. Data were collected during a 6-month period from May to October 2017, but verification took other four months (Up to February 2018). Data were obtained from official reports, legal documents, and interviews with key personnel and operators and also from official and unofficial dumpsites visits. In CoK, approximately 232,870 tons of MSW is generated per year, MSW collection and transportation is done by private companies but the only dumpsite present in Kigali is fully controlled by the City of Kigali. Residents pay waste collectors according to their social classes and their locations. There is no official recycling system; recycling activities are informally performed by private companies and some wastes, like plastic bottles, are taken to Uganda and Tanzania to be recycled. This study found that the recycling rate was $10 \%$ contrarily to the $2 \%$ which is recorded by official sources. This study has contributed by filling the gap in literature on waste management for the city of Kigali and it recommends that the Government represented by the CoK should do more in terms of investing in SWM and creating a relationship between private waste collectors and local communities, and the private sector should be mobilized to invest in SWM activities.
\end{abstract}

\section{Introduction}

Global Waste Management Outlook (GWMO) defined municipal solid waste as the waste from households and small businesses and institutions [1], however, the GWMO notes that the definition varies widely from country to country: that in Rwanda, the Solid waste is defined as all decayable and non-decayable solid and semi-solid wastes, such as trash, garbage, paper, refuse, rubbish, and ashes [2]. [3] mentioned that, although a lot of work has been done to control municipal solid waste disposal in low-income cities in developing countries, there is still some way to go to phase out uncontrolled disposal. In order to deal with SWM problems in developing countries, methods should be developed that can address the local complexities [4]. Furthermore, an approach known as integrated sustainable waste management (ISWM) allows municipalities or districts to manage MSW at the lowest possible cost $[5,6]$.

\subsection{City of Kigali}

The CoK is the capital of Rwanda, a landlocked country situated in the central/eastern part of Africa. Rwanda is bordered by Tanzania Burundi to the south. In 2016, the gross national income (GNI) per capita was US\$700, which is classified as a lower income economy. The CoK's population represents a tenth of the country's population. In 2012, 1,132,686 people resided in the CoK [7]. CoK has is now a home of around 1.5 million resident. CoK consists of three districts and it serves as the economic hub of the whole country. The $\mathrm{CoK}$ is facing critical challenges in solid waste management. The rapid increase in solid waste generation in the city and the improper disposal of the generated solid waste result in adverse impacts on health and environment, however, there is a lack of reliable data to assist decision makers for CoK's solid waste management.to the east, Uganda to the north, Democratic Republic of Congo to the west and

\subsection{Aim of this study}

This study aims at analyzing the current state of MSWM of CoK, Rwanda by applying systems analysis 
methodology of "wasteaware" benchmark indicators for integrated sustainable waste management in cities [8].

\section{Methodology}

The methodology adopted during this study is based on the city profiling methodology introduced by [1] and developed for UN-Habitat. The methodology was tested and used in more than fifty countries $[9,10,11 ; 3]$. This use validates the methodology [4].

In order to document and analyse the CoK overall system, a Sankey-style material flow diagram (MFD) was constructed using STAN2.5 software [12] (Figure 1)

The city profiling methodology is based on the integrated solid waste management (ISWM) concept [3]. Data were mainly collected during a 6-month period from May to October 2017, but verification took other four months (Up to February 2018) due to the complexity of municipal solid waste management in the CoK. Data were obtained from official reports and legal documents related to SWM in Rwanda, interviews with key personnel and operators, and also from official and unofficial visits to dumpsites.

\section{Material flow analysis for the combined MSWM and recycling system in Kigali}

Figure 1 shows the materials flow diagram (MFD) constructed to visualize the combined solid waste and recycling system in the CoK. The sources and methods used for each estimation in the MFD are summarized in Table 1.

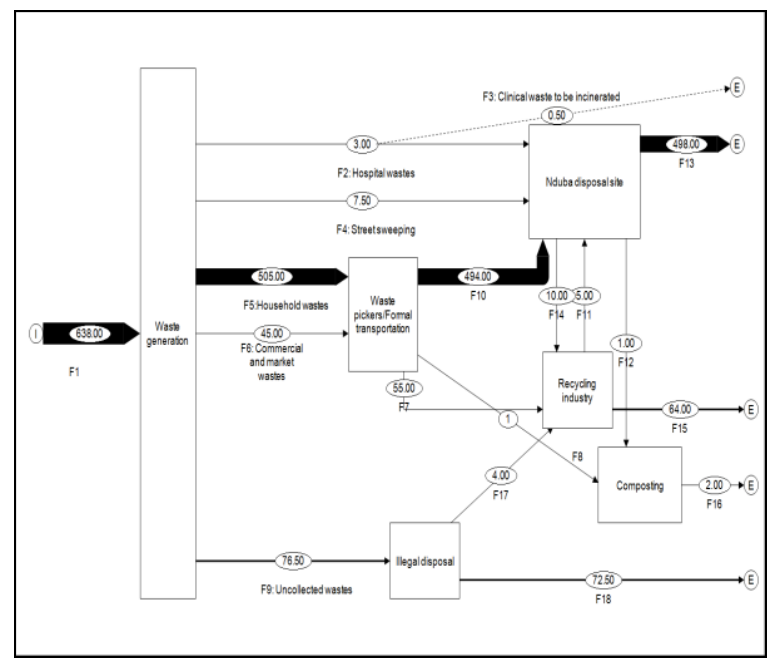

Fig 1. Sankey type material flow diagram (MFD) for MSW in the City of Kigali (the thickness of the flow corresponds to the waste value.)

There is an acute lack of data on waste management and recycling in $\mathrm{CoK}$. There are no weighbridges in daily use, so use had to be made of data on the number of vehicles arriving at the site from each source and on average loads. In 2014, vehicles were weighed at Nduba disposal site and only two types of vehicles were distinguished: one type carries 10 tonnes on average and the other 5 tonnes. Total waste generation is seldom measured. Here it is back-calculated from estimates of the quantities of waste collected and of collection coverage (see Table 1).

Table 1. Basis for calculating the waste flows for Kigali in the MFD

\begin{tabular}{|c|c|c|c|}
\hline $\begin{array}{l}\text { Flow } \\
s\end{array}$ & $\begin{array}{l}\text { Descriptio } \\
n\end{array}$ & Calculation & Basis for data \\
\hline F1 & $\begin{array}{l}\text { Total } \\
\text { Quantity } \\
\text { of waste } \\
\text { generated } \\
\text { in Kigali- } \\
\text { City }\end{array}$ & $\begin{array}{l}\text { Official data } \\
\text { give } \\
\text { collection } \\
\text { coverage } \\
\text { as } 88 \% \\
\mathrm{~F} 1=(\mathrm{F} 2+\mathrm{F} 4+\mathrm{F} \\
5+\mathrm{F} 6) / 0.88\end{array}$ & $\begin{array}{l}\text { Back-calculated } \\
\text { from collection } \\
\text { coverage and other } \\
\text { flows in MFD }\end{array}$ \\
\hline F2 & $\begin{array}{l}\text { Waste } \\
\text { from } \\
\text { official } \\
\text { Health } \\
\text { Centers } \\
\text { and } \\
\text { Hospitals }\end{array}$ & $\begin{array}{l}\text { Calculated } \\
\text { based on the } \\
\text { average load } \\
\text { delivered by } \\
\text { the vehicle. } \\
3 \text { vehicles a } \\
\text { week each } \\
\text { carrying } \\
\text { average load } \\
\text { of } 5 \text { tonnes. } \\
15 \text { tonnes } \\
\text { over } 6 \text { days, } \\
2.5 \text { tpd } \\
\text { collected. }\end{array}$ & $\begin{array}{l}\text { Vehicle numbers } \\
\text { and load size } \\
\text { provided by the } \\
\text { person in charge of } \\
\text { Nduba disposal site }\end{array}$ \\
\hline F3 & $\begin{array}{l}\text { Hazardou } \\
\text { s clinical } \\
\text { waste } \\
\text { (Incinerati } \\
\text { on is used } \\
\text { as } \\
\text { treatment } \\
\text { process) }\end{array}$ & $\begin{array}{l}\text { Assumes } \\
0.25 \text { kg per } \\
\text { bed per day } \\
\text { (cf WHO } \\
\text { guideline } 0.2 \\
\text { (Haifete et } \\
\text { al., } 2016 \text { )). } \\
\text { There are } \\
2000 \text { beds in } \\
\text { the } 5 \text { main } \\
\text { hospitals. }\end{array}$ & $\begin{array}{l}\text { Estimate by } \\
\text { authors, informed } \\
\text { by WHO data }\end{array}$ \\
\hline F4 & $\begin{array}{l}\text { Waste } \\
\text { from } \\
\text { street } \\
\text { sweeping/ } \\
\text { street } \\
\text { litter bins }\end{array}$ & $\begin{array}{l}9 \text { vehicles } \\
\text { per week } \\
\text { each carries } \\
5 \text { tonnes. } \\
45 \text { tonnes } \\
\text { over } 6 \text { days = } \\
7.5 \text { tpd }\end{array}$ & $\begin{array}{l}\text { Vehicle numbers } \\
\text { arriving at Nduba } \\
\text { disposal site }\end{array}$ \\
\hline F5 & $\begin{array}{l}\text { Waste } \\
\text { collected } \\
\text { from door } \\
\text { to door by } \\
\text { the } \\
\text { contracte } \\
\text { d private } \\
\text { companie } \\
\text { s. }\end{array}$ & $\begin{array}{l}30 \text { vehicles } \\
\text { per day } \\
\text { carrying } 10 \\
\text { tonnes }+41 \\
\text { vehicles per } \\
\text { day carrying } \\
\text { each } 5 \\
\text { tonnes. }\end{array}$ & $\begin{array}{l}\text { Vehicle numbers } \\
\text { and sizes arriving at } \\
\text { Nduba disposal site }\end{array}$ \\
\hline F6 & $\begin{array}{l}\text { Waste } \\
\text { collected } \\
\text { from } \\
\text { commerci } \\
\text { al } \\
\text { areas/mar } \\
\text { kets }\end{array}$ & $\begin{array}{l}9 \text { vehicles } \\
\text { per day } \\
\text { carrying } \\
\text { each } 5 \\
\text { tonnes }\end{array}$ & $\begin{array}{l}\text { Vehicle numbers } \\
\text { arriving at Nduba } \\
\text { disposal site }\end{array}$ \\
\hline F7 & $\begin{array}{l}\text { Wastes } \\
\text { collected } \\
\text { by the }\end{array}$ & $\begin{array}{l}\text { Estimated at } \\
10 \% \text { of flows } \\
\text { F4 and F5 }\end{array}$ & $\begin{array}{l}\text { Estimate by } \\
\text { authors based on } \\
\text { observation and }\end{array}$ \\
\hline
\end{tabular}




\begin{tabular}{|c|c|c|c|}
\hline & $\begin{array}{l}\text { private } \\
\text { companie } \\
\text { s and } \\
\text { separated } \\
\text { by their } \\
\text { employee } \\
\text { s for } \\
\text { recycling }\end{array}$ & $\begin{array}{l}\text { F7 = } \\
0.1^{*}(\mathrm{~F} 5+\mathrm{F} 6) \\
=0.1^{*} 550= \\
55 \mathrm{tpd}\end{array}$ & interviews \\
\hline F8 & $\begin{array}{l}\text { Organic } \\
\text { wastes } \\
\text { collected } \\
\text { directly } \\
\text { from the } \\
\text { source } \\
\text { and } \\
\text { transport } \\
\text { ed to } \\
\text { compost } \\
\text { plant }\end{array}$ & $\begin{array}{l}\text { Very small } \\
\text { flow. } \\
\text { Estimated at } \\
1 \text { tpd }\end{array}$ & $\begin{array}{l}\text { Estimate by } \\
\text { authors based on } \\
\text { observation and } \\
\text { interviews }\end{array}$ \\
\hline F9 & $\begin{array}{l}\text { Uncollect } \\
\text { ed wastes }\end{array}$ & $\begin{array}{l}\text { Waste } \\
\text { collection } \\
\text { coverage } \\
\text { equals } 88 \% \text {. } \\
\text { So, } 12 \% \text { is } \\
\text { not } \\
\text { collected. } \\
\text { Then F9 = } \\
12 \% \text { of F1 }\end{array}$ & $\begin{array}{l}\text { Collection coverage } \\
\text { calculated from } \\
\text { official data }\end{array}$ \\
\hline F10 & $\begin{array}{l}\text { Waste } \\
\text { delivered } \\
\text { to the } \\
\text { dumpsite } \\
\text { site from } \\
\text { household } \\
\mathrm{s}, \\
\text { commerci } \\
\text { al areas } \\
\text { and } \\
\text { markets }\end{array}$ & $\begin{array}{l}\text { Waste } \\
\text { collected } \\
\text { less the } \\
\text { quantity } \\
\text { separated } \\
\text { for recycling } \\
\text { F10= F5 + F6 } \\
\text { - F7 }\end{array}$ & $\begin{array}{l}\text { Calculated from } \\
\text { the MFD }\end{array}$ \\
\hline F11 & $\begin{array}{l}\text { Reject } \\
\text { materials } \\
\text { from } \\
\text { recycling } \\
\text { sent to } \\
\text { Nduba } \\
\text { disposal } \\
\text { site }\end{array}$ & Estimate & $\begin{array}{l}\text { Estimate by } \\
\text { authors based on } \\
\text { observation and } \\
\text { interviews }\end{array}$ \\
\hline F12 & $\begin{array}{l}\text { Organic } \\
\text { waste } \\
\text { sorted by } \\
\text { waste } \\
\text { pickers } \\
\text { from } \\
\text { Nduba } \\
\text { disposal } \\
\text { site, taken } \\
\text { to } \\
\text { composti } \\
\text { ng plant }\end{array}$ & Estimate & $\begin{array}{l}\text { Estimate by } \\
\text { authors based on } \\
\text { observation and } \\
\text { interviews }\end{array}$ \\
\hline F13 & $\begin{array}{l}\text { Dumpsite } \\
\text { materials }\end{array}$ & $\begin{array}{l}F 13=(F 2-F 3 \\
+F 4+F 10+ \\
F 11)-(F 14+ \\
F 12)\end{array}$ & $\begin{array}{l}\text { Calculated from } \\
\text { the MFD }\end{array}$ \\
\hline F14 & $\begin{array}{l}\text { Waste } \\
\text { sorted for } \\
\text { recycling } \\
\text { by pickers } \\
\text { at the } \\
\text { dumpsite } \\
\text { site. }\end{array}$ & $\begin{array}{l}\text { Estimate. } \\
\text { Mainly } \\
\text { plastic } \\
\text { bottles, } \\
\text { exported to } \\
\text { Uganda and } \\
\text { China }\end{array}$ & $\begin{array}{l}\text { Estimate by } \\
\text { authors based on } \\
\text { observation and } \\
\text { interviews }\end{array}$ \\
\hline
\end{tabular}

\begin{tabular}{|c|c|c|c|}
\hline F15 & $\begin{array}{l}\text { Recycled } \\
\text { materials }\end{array}$ & $\begin{array}{l}F 15=(F 7+ \\
F 17+F 14)- \\
F 11\end{array}$ & $\begin{array}{l}\text { Calculated from } \\
\text { the MFD }\end{array}$ \\
\hline F16 & $\begin{array}{l}\text { Fertilizer } \\
\text { from } \\
\text { Compost } \\
\text { plant. }\end{array}$ & $\begin{array}{l}\text { F16 = F8 + } \\
\text { F12. } \\
\text { Quantities } \\
\text { very small, } \\
\text { so no } \\
\text { attempt to } \\
\text { correct for } \\
\text { process } \\
\text { losses. }\end{array}$ & $\begin{array}{l}\text { Calculated from } \\
\text { the MFD. }\end{array}$ \\
\hline F17 & $\begin{array}{l}\text { Waste } \\
\text { sorted for } \\
\text { recycling } \\
\text { by waste } \\
\text { pickers on } \\
\text { illegal } \\
\text { dump- } \\
\text { sites }\end{array}$ & Estimate & $\begin{array}{l}\text { Estimate by } \\
\text { authors based on } \\
\text { observation and } \\
\text { interviews }\end{array}$ \\
\hline F18 & $\begin{array}{l}\text { Waste left } \\
\text { in illegal } \\
\text { dumpsites } \\
\text { after } \\
\text { waste } \\
\text { picking }\end{array}$ & $\begin{array}{l}\text { F18 = F9 }- \\
\text { F17 }\end{array}$ & $\begin{array}{l}\text { Calculated from } \\
\text { the MFD }\end{array}$ \\
\hline
\end{tabular}

\section{Systems analysis of the MSWM and recycling in Kigali}

\subsection{Waste generation and composition}

According to the most recent Rwanda Population and Housing Census (RPHC4), the population of Kigali in 2012 was 1,132,686 [7]. The growth rate since 2002 has been $2.6 \%$ per annum [7]; using this to extrapolate forward to 2017, the population used here is 1,574,000.

The MFD (Figure 1) estimated waste generation at 638 tonnes per day, or 233,000 tonnes per year. This corresponds to a per capita MSW generation of of 0.41 $\mathrm{kg} /$ day, or $148 \mathrm{~kg} / \mathrm{year}$. No specific data could be located for waste composition in Kigali or Rwanda. We have used data from a 2012 planning study, which did not measure waste composition directly but instead used figures 'typical for a low income country': organics $70 \%$ by weight; paper $6 \%$; plastic $5 \%$; and metals $3 \%$ [13]. No data are available for waste density, moisture content or calorific value.

\subsection{Waste collection}

The official report from the Office of the Auditor General of State Finances, Rwanda mentioned that only $2 \%$ of solid waste is recycled, but our investigation has shown the recycling rate to be $10 \%$ (55 tonnes per day). The $10 \%$ rate represents separated wastes collected by private companies, from households and commercial areas for recycling. The basic system is that householders store their waste in individual containers, which are collected door-to-door once a week; while commercial areas and markets use communal containers (sizes of containers are $60,120,240,660,1100$ liters)or walled collection bays (sizes of walled collection bays is 
$7 \times 4 \times 2.5 \mathrm{~m}^{3}$ ), from which waste is collected daily. The system works reasonably well, with three medium/high compliance scores of 15/20 and three of 10/20, giving an overall score of $63 \%$, i.e. a medium/high assessment for the quality of waste collection and street cleaning.

\subsection{Waste treatment and disposal}

There is only one disposal site in Kigali city, called Nduba after its location in Gasabo district. The site started operations in 2012 and is run by the City. Nduba scores 5 or $10 / 20$ on the three 'quality criteria', which categorises it as semi-controlled, below the threshold set for controlled disposal. As there is no controlled disposal facility in use in Kigali, the Wasteaware 'controlled disposal' indicator is $0 \%$. The quality indicator is rated Medium/Low (30\% score)

\subsection{Resource Management}

The overall assessment is Low/Medium, with a score of $33 \%$ In the CoK, awareness support for waste separation at the source (householders and offices) is very high but people do not separate waste at the source. In the past, communities used to sort and separate the waste at the source, but due to irregular collections they lost trust in the waste collectors. Regular collection of the sorted waste increases trust from service users [14].

\subsection{Governance}

\subsubsection{User Inclusivity (UI)}

The benchmark indicator for user inclusivity assesses citizens' and other waste generators' inclusion in the waste management system. The overall assessment is medium/high, with a score of $71 \%$. Access of users to services is generally good. Numerous systems are in place for citizens to make their voices heard, including environmental committees at 4 levels of local government from the 'cell' upwards, which then pass on their concerns either at formal monthly meetings with CoK officials, or through the monthly 'Umuganda' community service day. The CoK carries out proactive public awareness and education, but is constrained by lack of resources. The evidence for people actually 'doing the right thing' is also strong.

\subsubsection{Provide Inclusivity (PI)}

The score here was found to be 55 which represents medium as an overall assessment. Generally In the CoK, private companies in charge of SW collection provide high quality service.

\subsubsection{Financial Sustainability}

Financial sustainability benchmark indicators assess how the city's SWM service is financially sustainable. Total score is $50 \%$ which corresponds to medium as an overall assessment. According to one in charge of SWM under the CoK, the budget allocated to SWM is not sufficient.

\subsubsection{Sound institutions and proactive policies: National SWM Framework}

These benchmark indicators assess the adequacy of the national solid waste management framework; this assessment also includes the degree of implementation. The overall assessment is medium, with a score of $58 \%$. In Rwanda there are a lot of legislations and regulations on SWM but their enforcement is weak (for example there is prohibition of manufacturing, importation, use and sale of polythene bags in Rwanda but still some people use plastic bags illegally entered into Rwanda).

\subsubsection{Sound institutions and proactive policies: Local Institutional Coherence}

These assess the institutional strength and coherence of the city's solid waste management functions. The overall assessment is medium, with a score of $50 \%$.

The level of collaboration between governmental institutions and private companies is sufficient. Data availability is limited at Nduba disposal site (no weighbridge, nothing about waste generation etc...). There is an urgent need to improve data collection, reporting methods and monitoring methods.

\section{Discussion}

This study has assessed the CoK's MSWM. People in the CoK generate wastes equal to 232,870 tonnes/year and waste generation per capita is equal to approximately half ( $405 \mathrm{~g} /$ capita/day) of a higher waste generating city (above $1 \mathrm{~kg} /$ capita/day). This explains that the CoK belongs to lower generating cities and then there is no urgency of waste reduction, apart from the issue to take critically the diversion from treatment and disposal to recycling.

For public health-waste collection category, CoK showed a strong performance. Regarding, the environmental control-waste category, CoK performes well, however, there is still more to be done, CoK should make efforts to improve environmental protection measures, a waste treatment plant should be built at Nduba disposal site, leachate should be controlled and workers at Nduba disposal site should be protected. The score for recycling rate was low and this shows that Rwanda needs a strong improvement in order to increase the recycling rate. For $\mathrm{CoK}, 3 \mathrm{R}$ (reduce, reuse, and recycle) quality indicators scored $33 \%$. This score is classified as low-medium performance and in order to improve $3 \mathrm{R}$ quality indicators the CoK should urgently start concentrating its efforts on recycling activities.

Table 2. Wasteaware benchmark indicator results for Kigali city

\begin{tabular}{|l|l|l|l|l|}
\hline No & Category & Indicator & & \\
\hline & City & & Kigali & \\
\hline & Country & & Rwanda & \\
\hline
\end{tabular}




\begin{tabular}{|c|c|c|c|c|}
\hline \multicolumn{2}{|c|}{$\begin{array}{l}\text { Background information } \\
\text { on the city }\end{array}$} & & & \\
\hline & \multirow[t]{2}{*}{ Country income level } & $\begin{array}{l}\text { World Bank income } \\
\text { category }\end{array}$ & Low & \\
\hline B1 & & GNI per capita & $\$ 700$ & \\
\hline B2 & Population & $\begin{array}{l}\text { Total population of the } \\
\text { city }\end{array}$ & $1,574,434$ & \\
\hline B3 & Waste generation & $\begin{array}{l}\text { MSW generation (tones } \\
\text { per year) }\end{array}$ & 232,870 & \\
\hline \multicolumn{4}{|c|}{ Key waste-related data } & \\
\hline W1 & Waste per capita & $\begin{array}{l}\text { MSW per capita (kg per } \\
\text { year) }\end{array}$ & 148 & \\
\hline W2 & & Waste composition & & \\
\hline W2.1 & Organic & $\begin{array}{l}\text { Organic (foods and } \\
\text { green waste) }\end{array}$ & $70 \%$ & \\
\hline W2.2 & Paper & Paper and card & $6 \%$ & \\
\hline W2.3 & Plastic & Plastic & $5 \%$ & \\
\hline W2.4 & Metals & Metals & $3 \%$ & \\
\hline \multicolumn{5}{|c|}{ Physical components } \\
\hline 1.1 & \multirow[t]{3}{*}{$\begin{array}{l}\text { Public health-waste } \\
\text { collection }\end{array}$} & $\begin{array}{ll}\begin{array}{l}\text { Waste } \\
\text { coverage }\end{array} & \text { collection } \\
\end{array}$ & $88 \%(\mathrm{M})$ & \\
\hline 1.2 & & $\begin{array}{l}\text { Waste captured by the } \\
\text { system }\end{array}$ & $88 \%(\mathrm{M})$ & \\
\hline $1 \mathrm{C}$ & & $\begin{array}{l}\text { Quality of waste } \\
\text { collection service }\end{array}$ & $\begin{array}{l}63 \% \\
(\mathrm{M} / \mathrm{H}) \\
\end{array}$ & \\
\hline 2 & \multirow[t]{2}{*}{$\begin{array}{l}\text { Environmental } \\
\text { control-waste }\end{array}$} & $\begin{array}{ll}\begin{array}{l}\text { Controlled } \\
\text { and disposal }\end{array} & \\
\end{array}$ & 79 (M) & \\
\hline $2 \mathrm{E}$ & & $\begin{array}{l}\text { Degree of environmental } \\
\text { protection in waste } \\
\text { treatment and disposal }\end{array}$ & $30(\mathrm{~L} / \mathrm{M})$ & \\
\hline 3 & \multirow{2}{*}{$\begin{array}{l}\text { Resource } \\
\text { management- } \\
\text { reduce, reuse and } \\
\text { recycle }\end{array}$} & Recycling rate & $\begin{array}{l}10 \% \\
(\mathrm{~L} / \mathrm{M}) \\
\end{array}$ & \\
\hline $3 R$ & & $\begin{array}{l}\text { Quality of 3Rs- Reduce, } \\
\text { reuse, recycle-provision }\end{array}$ & $33 \%(\mathrm{~L} / \mathrm{M}$ & \\
\hline \multicolumn{5}{|c|}{ Governance factors } \\
\hline $4 U$ & \multirow[t]{2}{*}{ Inclusivity } & User inclusivity & $\begin{array}{l}71 \% \\
(\mathrm{M} / \mathrm{H})\end{array}$ & \\
\hline $4 \mathrm{P}$ & & Provider inclusivity & $55 \%(\mathrm{M})$ & \\
\hline $5 \mathrm{~F}$ & $\begin{array}{l}\text { Financial } \\
\text { sustainability }\end{array}$ & Financial sustainability & $50 \%(\mathrm{M})$ & \\
\hline $6 \mathrm{~N}$ & Sound institutions & $\begin{array}{l}\text { Adequacy of national } \\
\text { SWM framework }\end{array}$ & $58 \%(\mathrm{M})$ & \\
\hline $6 \mathrm{~L}$ & Proactive policies & $\begin{array}{ll}\text { Local institutional } \\
\text { policies }\end{array}$ & $50 \%(\mathrm{M})$ & \\
\hline
\end{tabular}

For user inclusivity qualitative indicator (4U), the score was good $(71 \%)$ and only needed improvement in the consideration of local communities' contributions to decisions. Regarding the provider inclusivity qualitative indicator (4P), the score was $55 \%$. The most needed improvements are the representation of the private sector and the integration of the informal sector into the formal WMS because they have knowledge on waste composition and recyclables [4].

The score for financial sustainability was found to be $50 \%$ and below for four cities out of five except Maputo which scored $67 \%$, this shows that the financial sustainability of the SWM system is a major challenge in the CoK and in other cities of developing countries [4]. This financial sustainability challenge can be overcome by sensitizing the private sector to invest in solid waste management and sensitize local communities to work closely with the private sector. In the eyes of local communities, private companies in charge of waste collection are seen as companies which are only after money. A lot of effort should be made to build a strong relationship between the private sector and local communities. The city has good policies, strategies, legislation and regulations but the problem is the implementation. For example, CoK has ten sets of good strategies but none of them has been implemented so far
(6N). Government institutions and the CoK (6N and 6L) in particular have to make sure that all those good strategies and policies are fully implemented.

\section{Conclusions and recommendations}

This paper has presented the SWM profile of the CoK. The country has adopted a lot of strategies to protect the environment such as the legal ban on use of nonbiodegradable plastic bags. Despite making a lot of effort towards SWM improvements, there are still considerable improvements to be made. The study showed that data such as moisture content and solid waste density are not known. In order to raise the standard of solid waste management in the $\mathrm{CoK}$, this lack of data problem should be addressed.

In order to conduct this study a systems analysis methodology of "wasteaware" benchmark indicators for integrated sustainable waste management in cities was applied. For allowing a visualization of the MWMS in the CoK a MFD diagram was provided to accompany the "wasteaware" benchmark indicators.

This study estimated the MSW generation rate in the $\mathrm{CoK}$ at $0.405 \mathrm{~kg} / \mathrm{capita} /$ day with a total 638 tonnes per day of waste. In order to estimate the waste generation per capita, the number of vehicles bringing waste at Nduba disposal site of the City of Kigali were used. The major information found during this study is the recycling rate of $10 \%$, which is contrary to the recycling rate from official sources $(2 \%)$. In terms of sound institutions and proactive policies, both national SWM and local institutional coherence are rated medium (the scores were $58 \%$ and $50 \%$ respectively). The only needed improvement here is to monitor the implementation of suitable proposed policies/strategies.

Government represented by the CoK should do more in terms of creating a relationship between private waste collectors and local communities so that local communities stop looking at these private companies as only money-oriented companies. The private sector should be sensitized to invest in SWM activities. The $\mathrm{CoK}$ and private waste collecting companies should also improve working conditions for their workers.

\section{Reference}

1. Wilson C David C, Rodic Ljiljana, Cowing J Michael, Velis A Costas, Whiteman D Andrew, Scheinberg Anne, Vilches Recaredo, Masterson Darragh, Stretz Joachim and Oelz Barbara (2014) 'Wasteaware' Benchmark Indicators for Integrated Sustainable Waste Management in Cities. Supporting Information For paper published in Waste Management - doi: 10.1016/j.wasman.2014.10.006. Available at http://wasteaware.org/wpcontent/uploads/2015/11/Wilson_et_al_Supplementa ry_information_Wasteaware_ISWM_Benchmark_In dicators_User_Manual_Online.pdf 
2. MININFRA (2016) National Sanitation Policy, Kigali-Rwanda. Available at: http://www.rura.rw/uploads/media/NATIONAL_SA NITATION_POLICY_DECEMBER_2016.pdf.

3. Wilson C David, Rodic Ljiljana, Scheinberg Anne, Velis A Costas and Alabaster Graham ( 2012) Comparative analysis of solid waste management in 20 cities, Waste Management \& Research 30(3) 237-254.

4. Byamba Bolorchimeg and Ishikawa Mamoru (2017) Municipal Solid Waste Management in Ulaanbaatar, Mongolia: Systems Analysis, Sustainability 2017, 9, 896; doi:10.3390/su9060896.

5. Anschütz, J., IJgosse, J. and Scheinberg, A. (2004) Putting ISWM to Practice. Using the ISWM Assessment Methodology, ISWM Methodology as applied in the UWEP Plus Programme (2001-2003), WASTE, Gouda, The Netherlands.

6. Van de Klundert, A. and Anschütz, J. (2001) Integrated Sustainable Waste Management - the concept. Tools for decision-makers, Experiences from the Urban Waste Expertise Programme (19952001), WASTE, Gouda, the Netherlands.

7. National Institute of Statistics of Rwanda (2012) The fourth Population and Housing Census in Rwanda. Available at: http://microdata.statistics.gov.rw/index.php/catalog/ 65 .

8. UNEP and ISWA (2015). Global Waste Management Outlook. Editor-in-Chief: Wilson D C Authors: Wilson D C, Rodic L, Modak P, Soos R, Carpintero A, Velis C A, Iyer $\mathrm{M}$ and Simonett $\mathrm{O}$. Prepared for UNEP and ISWA. Osaka: UNEP. Available at: https://www.researchgate.net/publication/283085861
_Global_Waste_Management_Outlook_United_Nati ons_Environment_Programme_UNEP_and_Internati onal_Solid_Waste_Association_ISWA (Accessed 13.07.2018)

9. Al Sabbagh MK, Velis CA, Wilson DC and Cheeseman CR (2012) Resource management performance in Bahrain: a systematic analysis of municipal waste management, secondary material flows and organizational aspects. Waste Management \& Research 30 (8):813-824.

10. Masood, M.; Barlow, C.Y.;Wilson, D.C. (2014) An assessment of the current municipal solid waste management system in Lahore, Pakistan. Waste Manag. Res. 32: 834-847.

11. Sim, N.M.; Wilson, D.C.; Velis, C.A.; Smith, S.R. (2013) Waste management and recycling in the former Soviet Union: The City of Bishkek, Kyrgyz Republic (Kyrgyzstan). Waste Manag. Res. 31: 106125.

12. Cencic O and Rechberger H (2008) Material flow analysis with software STAN. Environmental Engineering and Management Journal 18: 3-7.

13. BURGEAP (2012) Solid waste management plan final report. Report to City of Kigali, funded by Belgian Government. Kigali, Rwanda.

14. Kodwo Miezah , Kwasi Obiri-Danso , Zsófia Kádár, Bernard Fei-Baffoe, Moses Y. Mensah(2015) Municipal solid waste characterization and quantification as a measure towards effective waste management in Ghana. Waste Management 46 (2015) 15-27.

15. Kawai Kosuke; Tasaki Tomohiro (2016) Revisiting estimates of municipal solid waste generation per capita and their reliability, J Mater Cycles Waste Manag 18:1-13 DOI 10.1007/s10163-015-0355-1. 